\title{
Counter-Bioinvasion: Conceptual and Governance Challenges
}

Final version: $\underline{\text { http://www.tandfonline.com/doi/abs/10.1080/09644010701251672 }}$

\section{Introduction}

The specter of invasion has implicitly informed much of our thinking about the state as a political entity. The popular history of warfare, pre and post-colonial, is centered on the threat, conduct, and repulsion of invasion and counter-invasion, insurgency and counter-insurgency. These terms are used strategically, to demarcate polarities such as friend and foe, citizen and alien, inside and outside, security and threat, self and target. Yet, it could be argued that the most common form of invasion takes place at the environmental level, on a daily basis, and it is becoming more common with each passing year as both trade and production relocation processes afford invasive alien species (IAS) new opportunities. Those who study environmental politics need to take bioinvasion as a serious conceptual and governance challenge. And, since invasive species are international actors today, we need in particular to integrate this issue-area within the subfield of global ecopolitics.

There are related historical themes, most notably that of ecological imperialism, with biological agents playing the role of colonizing accomplice, or with northern industrial states invading the south with toxic waste. This can be stretched to include biomanipulation (or environmental alteration) which largely serves the commercial interests of the North; extreme cases, such as the introduction of the Nile perch, the Tanganyika sardine, and water hyacinth into Lakes Victoria, Kyoga, Nabugabo, Kariba, Kiw, Itezhitezhi, and Malawi, have been referred to as Darwinian nightmares. ${ }^{1}$ Modern pandemics such as AIDS and SARS, the resurgence of old ones such as malaria, and the threat of new ones such as a human-human transmitted H5N1 avian flue, have captured the attention of journalists and global health governance experts alike. Perhaps the globalization of such microbial threats to human security demonstrates the "obsolescence of the traditional distinction between national and international health threats" (Aginam, 2005: 46).

But what of the myriad threats to natural ecosystems posed by invasive species at the biotic level? The economic damage inflicted by mass bioinvasions - arguably, a byproduct of globalization (Van Driesche, 2000; Bright, 1999) - has been as obvious as it has been largely ignored by those engaged in the study of environmental politics. This is especially evident in the field of International Relations (IR). Of course, not all IAS cross borders, which might render them non-IR material to some; but many do, and scientists

\footnotetext{
${ }^{1}$ The reference here is to the popular socio-political documentary, "Darwin's Nightmare" directed by Hubert Sauper and released in 2005.
} 
believe this will increase as climate change prompts bioinvasion. Perhaps the topic proves challenging - and thus understudied - because it questions long-cherished positions on the constitution of security and, thus, territorial protection. It also challenges some basic optimistic liberal assumptions about the value of unfettered trade; and for environmentally-concerned IR specialists, it also raises the ugly question of when nature must be destroyed in order to protect it from itself. At the very least some uncomfortable introspection within advanced capitalist societies should be forthcoming, since industrial agriculture, including the spread (purposive and incidental) of genetically modified organisms (GMOs), is contingent on the assumption that some IAS are 'better' than others. Finally, it is noteworthy that nature itself is a cultural construct, subject to different understandings across time and space (see Greenough and Lowenhaupt, 2004), and the framing of threats to nature will mirror that normative context.

Invasive species, like air and water pollution, do not recognize borders, and will follow their own 'natural' destiny unless human intervention or natural disaster stops them. While it is tempting to conclude that, as with anthropogenic forms of transborder pollution, we can usually lay the blame for such events on individuals, firms, large corporations, even entire public administrative infrastructures, the reality is that we are dealing with the opportunistic patterns of nature as much as that of any human culprit. Does this put us back in the day of Locke, when market forces were seen as the salvation from the domination of an invasive natural world? Does this call for the ecofascism extolled by a loose reading of Hardin (1968) and others, demanding some form of state authoritarianism (co-operative on the international level, of course - unless a hegemon is able/forced to apply coercive pressure)? Can the multilateral managerial approach evoked by the term 'global governance' emerge as the most credible approach to such 'interdependence challenges'? Or will a fortress mentality prevail, wherein mass quarantine and the closing of borders to suspicious trade renders predictions of further globalization or transnational development moot? Indeed, there are many ways to frame the issue: the tendency at the international level, it is surmised here, will be to treat it as a global governance challenge, to provide "counter-bioinvasion" policies, and as such this article will focus on that dimension. Put simply, this is neither as simple or easy as it may sound.

This article is composed of three essential parts. We begin by defining the problem of invasive alien species, and their international characteristics. Though some ecoholists might take issue, we will certainly define them as "problems", not only because of the economic damage they often inflict, but because of the ecological damage for which they are infamous. Next we move to a discussion of some of the conceptual implications of treating bioinvasion as a serious topic in both environmental politics and global ecopolitics. This is a significant step, but it is problematic on several levels: it encourages parochial, NIMBY thinking, and relies on an old ecological paradigm that assumes natural equilibrium is a desirable trait. I argue both these problems are overcome by the human security imperative of protecting civilians from the most harmful effects of bioinvasion, but acknowledge that this conceptual conundrum will continue to confuse our thinking, and should indeed temper the zeal with which eradication campaigns are adopted. The third section explicitly visits some of the more concrete governance 
problems raised by IAS, at the international but, arguably, all levels of governance. These include the division of labour and authority, the question of blame and compensation, the need for sustained public attention on the issue, as well as the integration of the natural and social/policy sciences and the omnipresent uncertainties associated with climate change.

\section{Invasive Alien Species}

The Japanese kudzu weed, introduced to the United States in 1876, now covers three million acres (CEC, 2001); the Asian carp, which escaped from Arkansas catfish farms in the early 1990s, eats almost half of its weight in plankton and vegetation every day and is on the verge of invading the North American Great Lakes; Spain, Portugal, Morocco and France have all embarked on an eradication program to free the rare whitetailed duck from further incursions by sun-seeking ruddy ducks; giant bullfrogs in British Columbia $^{2}$ have developed a wide-ranging appetite for other amphibians, ducklings, garter snakes, songbirds, and even mice; aggressive Canadian beavers continue to wreak havoc in the marshlands of Chile and Argentina. ${ }^{3}$ The infamous zebra mussel has clogged large swaths of the Great Lakes, demonstrating extraordinary hitch-hiking skills and raising transborder policy co-ordination issues (see Sanders and Stoett, 2006). Indeed, the adaptive skills and sheer audacity of invasive alien species (IAS), which traverse borders and infest the commons without human permission, give rise to broader and perhaps ancient fears about our inability to overcome the strength of nature on the one hand, and alarming uncertainty about our own impact on the earth on the other.

Two basic factors determine species distribution: one is immediately ecological, the other historical. The first refers to characteristics of the local environment in which a species exists; this determines the physiological tolerances and ecological niche, or the environmental conditions within which a species can maintain population without migration. Historical factors refer to constraints of the physical landscape that permit or prevent species from arriving in a particular region. Oceans, rivers, deserts, and mountains are barriers to species colonization. Though these barriers are very difficult to transverse, inadvertent human transport has enabled species to find new ecological niches far away from their native habitat (CBD, 2001a), and if there are no natural predators in the way, they can flourish with dazzling speed.

\footnotetext{
${ }^{2}$ N. Read, “Gigantic Killer Frogs Overrun B.C.”, National Post, July 8, 2004, A1.

${ }^{3}$ The Beavers were introduced in the late 1940s, and have multiplied from a small group to the hundreds of thousands, especially in the Tierra del Fuego region in Argentina. See Lizarralde, 1993; and an article in the Epoch Times in which the claim is made that "The animals, which are normally herbivores, have also taken to eating fish in South America, giving rise to a new generation of super-sized beavers building dams up to 100 meters-long"; I. Alescio, "Canadian Beavers Invade Argentina”, Jan. 26, 2006.
} 
Invasive species are everywhere, of course, so we should clarify the purposive use of the term. Much has changed since Charles Elton first published his groundbreaking book on The Ecology of Invasions by Animals and Plants in 1958. But with his concern for the habitat of affected areas and possible impact on human health, he was certainly on to something. Presently, an entire field of study has evolved, commonly referred to as invasive biology, dedicated to the study of such phenomena (see Vermeij, 1996). Typically, the term "alien species" refers to one occurring outside its normal distribution range; an invasive species is not only alien, but threatens the existence of indigenous or endemic species. ${ }^{4}$ Of course, the connotation is self-evident: these are bad things, which threaten plant, animal, forest, and humans alike. Indeed, they are largely considered a form of biological pollution, and "one that is likely to be longer lasting than chemical pollution" (CEC, 2001: 39). Some invading species pack terrible luggage, such as infectious diseases that can take human life (Louribos, 2002), but they are at the very least lethal to native plants, marine life, and mammals. ${ }^{5}$

Of course, the ultimate invasive species, and the one with the uncontested title for "most ecological damage done", is humankind. ${ }^{6}$ Indeed, for several centuries, bioinvasion has been a global affair based largely on human-mediated global dispersal. Reasons for deliberate introductions include biological pest control (Simberloff and Stiling, 1996), and the introduction of game species for hunting and fishing purposes. This latter is common in North America, where the Great Lakes (after being ravaged by the invasive sea lamprey) have been populated largely by introduced species, and where species such as ring-necked pheasant and sika deer have been introduced for hunting purposes (Cox, 1999); it also a serious problem in the Mediterranean (Crivelli, 1995), African, and other regions. Such introductions have been labeled "crimes against biodiversity" (Courtenay and Moyle, 1992); the Nile perch's disastrous effect upon East Africa's Lake Victoria has been labeled "the first mass extinction ever witnessed, and felt, and intensely analyzed" (Kaufman, 1993:42). And yet, we should temper this tendency to stress the most deleterious impact with the realization that nature never sits in vacuum, and that IAS are a permanent feature of any natural setting. The modern distinction, as is often enough the case, is that unprecedented levels of commerce, production, and climate change accelerate their spread.

The most commonly accepted definition of invasive species is probably "widespread nonindigenous species that have adverse effects on the invaded habitat" (McNeely, et. al., 2001; but see also Colautti and MacIsaac, 2004). Many other terms have been used to refer to this phenomenon: nonindigenous, exotic, introduced, noxious, weed, nuisance, colonizing, and transient are but a few. Space does not permit a detailed

\footnotetext{
${ }^{4}$ This is distinct from migratory species, defined in the 1979 Convention on the Conservation of Migratory Species of Wild Animals as "the entire population or any geographically separate part of the population of any species or lower taxon of wild animals, a significant proportion of whose members cyclically and predictably cross one or more national jurisdictional boundaries"; Article 1.1(a).

${ }_{5}^{5}$ Price-Smith refers to the tiger mosquito larvae that "traveled across the Pacific in small pools of water present in used tires that were shipped back to the United States for retreading. ...the dengue virus that it transmits has followed suit in synergistic fashion" (2002:166); see also Reiter and Sprenger, 1987. ${ }^{6}$ See di Castri, 1989, for an excellent survey of the mutual impact of human history and biological invasions. A thorough update is needed. For as recent American treatment see Leland, 2005.
} 
examination of these alternative terms, which may all, to differing degrees, be problematic. ${ }^{7}$ Even the term "invasive species" has such a negative connotation that observers have charged the entire subfield with "over-emotionalizing" the issues involved, thus betraying the standards of dispassionate science (Theodoropoulas, 2003). Yet in order to capture public attention and reflect the pervasive nature of major species' migration events, the term "invasion" would seem justified (one usually reserves the term "plague" for events more directly harmful to humans). There are also ongoing debates about what criteria should be employed to distinguish nonindigenous from indigenous species; usually such factors as fossil and historical evidence, geographic distribution, genetic diversity, the plausibility of hypotheses for means of introduction, and reproductive patterns are used (see Schwartz, 1997).

There is no empirical doubt that certain species have spread over thousands of miles and caused irreparable harm to local species, and examples abound. IAS do more than challenge local food competitors: they can even alter the fundamental characteristics of ecosystems. Beyond the Nile perch disaster mentioned above, other deliberate introductions have had deleterious impacts. For example, efforts to eradicate larval mosquito by way of introducing predatory fish have had negative impacts on other species of fish, insects, and amphibians (see Goodsell and Kats, 1999). The deliberate introduction of so-called biological-control agents can release them from the constraints imposed by their natural enemies, further homogenize the world's biotic communities, and affect non-target species as well; they can also lead to unpredictable evolutionary changes (Edwards, 1998). Thus one of the major concerns with GMOs, which are deliberately introduced IAS, with all the scientific and policy uncertainty that entails.

Invasion biology aside, the main reason IAS is a policy issue, and not just a scientific and academic one, is the fear of human harm. History is full of microbial examples, such as the indigenous peoples harmed by foreign microbes brought over by the Europeans during colonization (see Crosby, 1986). More recently, the West Nile virus, spread by mosquitoes and birds, was first found in 1937 in Uganda, and was located by 1999 in New York (see Lounibos, 2002). Species can be vectors for serious diseases as well as invasive species of their own right: for example, a virus that causes hemorrhagic fever is said to have found its way to Baltimore from Seoul by way of wharf rats that made the journey in cargo ships (see Pirages, 1996). There are, of course, nonhuman mediated dispersals, such as so-called "kelp rafts" in the sub-Antarctic (see Smith, 2001), ice flows in the Arctic, changing wind patterns, and other factors. But these are not known to cause lengthy migrations; this requires a combination of human invention and ignorance. The spread of purple loosestrife and the zebra mussel in North America are prolific examples of how trade has facilitated IAS, one delivered by wooden ships and wind, the other by steel cargo ships, ballast tanks and propeller.

\footnotetext{
${ }^{7}$ Interestingly, they all seem to connote a different level of human culpability in their existence. For example, we tend to think of weeds as natural; they invade carefully manicured lawns because they can, not because the lawns are relatively new micro-ecosystems in themselves. "Introduced" species, on the other hand, are clearly the consequence of human design, whether or not the intention involved ecocide. "Colonizing" is perhaps the most interesting term, not only because it applies also to many species of ants and bees that create colonies without invading other ecosystems, but because colonization is, after all, one of the more historically prominent human endeavors.
} 


\section{Conceptual Dilemmas}

There are several conceptual dilemmas associated with the scientific study of invasive species. One is taxonomic. Do we include only deliberately introduced species, or those that are migrating of their own accord (but are perhaps stimulated to do so by anthropogenic causes such as global warming), or incidental cases, where human activity has directly but unknowingly contributed? Most specialists suggest we should include all of these cases, provided the species has a profound impact on its new location. Usually, however, this implies that there is some level of nuisance to human affairs involved. Indeed, without a sudden and prolonged economic impact, it is doubtful invasive species would encourage even the limited public and governmental interest they do today. Of course, we also have to consider the possibility that bioinvasions will be deliberately introduced in order to inflict harm on ecosystems (ecocide) or used as weapons against human populations (bioterrorism). This has happened in the past (see Miller et. al., 2001) and probably will happen in the future, despite various multilateral efforts to curb such behavior. While the generally slow speed of spread for deliberately introduced organisms probably renders this approach to sabotage less likely, the threat of microbial and virus introductions is of course a permanent concern. ${ }^{8}$

But we need not delve in the realm of bioterror to appreciate the potential impact of IAS, which can act in a multitude of ways to have a negative impact on both natural and human systems: they can stimulate fires, deplete water, cause disease, decimate crops, disrupt fisheries, impede navigation, clog water works, destroy gardens, grazing land, and agriculture, eliminate entire species, and alter evolutionary paths (CBD, 2001: 2-3). Prevention efforts are vital, and have already formed a cottage industry within the grander field of international conservation management, and legal efforts to redress the economic harm caused by invasive species will no doubt grow at the speed of purple loosestrife spread itself. However, we must approach the question of invasive alien species with a certain element of resignation. This is, on the one hand, a natural process, as ugly as it may seem to our aesthetic senses. The fact that it is often the result of economic activity - it is, to some degree, our own undoing of our natural life base - can inject a sense of both urgency and guilt into this equation. But this does not override an essential reality: the invaders are here to stay.

Ultimately, the management of these issues will be a function of their presentation, representation and misrepresentation by media, government, NGO, and industry alike. With invasive species and infectious disease, we can predict patterns of prevalence, but would be foolish to believe we can do so with great accuracy, or enough to eliminate the element of surprise. Environmental change is even less manageable. But what may be needed, more than ever, is a healthy dose of introspection. Many of the invasive species we face today are approaching northern states because of economic

\footnotetext{
${ }^{8}$ Interestingly, many indigenous groups would view the introduction of non-native crops as a form of bioterrorism practiced over several centuries, and concerns with GMOs echo this sentiment; the extraction of indigenous species without adequate compensation to native dwellers is, in turn, considered biopiracy.
} 
processes that need to be tightly regulated if we stand a chance of controlling further spread. Similarly, the processes of mass industrialized agriculture - the feeding of bovine spinal matter to cattle, the close quarters in chicken coops, the water contamination resultant from excessive untreated farm excrement, the overuse of antibiotics - are responsible for the speed with which biosafety can be compromised, an agricultural model that continues to be exported to the southern hemisphere.

To some extent, of course, invasive species are natural phenomena, perhaps inviting paternalistic intervention (Feinberg, 1986; VanDeVeer, 1986), but hardly challenging the structure of the contemporary capitalist/industrial state system. Anthropomorphic contributions cloud this mechanistic version of the story, since in many cases they are a function of the agricultural and industrial processes on which the globalized economy has become dependent, making bioinvasion a permanent feature of the ecological, and political, landscape. And though the discourse has been somewhat muted by broader concerns, such as climate change, the impact of invasive species on biodiversity and economic opportunities will eventually manifest itself at a more pronounced international level. Invasive species will become the stuff of IR, and the concepts guiding the various perspectives on how best to conduct the discipline will at least partially determine the navigation of the topic. We certainly need to encourage an onslaught of related institutional analyses of remedial action plans -- for example, the North American Great Lakes provide an experimental foray (see Sproule-Jones, 2002) -but universally legalized codes of conduct related to IAS elude us.

In general, IAS is a theme that can put many observers on uncomfortable ground. For example, the preservationist-conservationist divide so common is wildlife protection organizations and debates (see Stoett, 2004) seems utterly out of place here; both sides would agree that IAS are threats to wildlife, yet IAS are, in essence, wildlife. Green activists also find this a perplexing ethical issue. There may be some ecowarriors who would simply advocate sinking all ballast-water carrying ships, or throwing other wrenches in the machinery of global trade. But in order to preserve an ecosystem as an integral place, it may be necessary to so isolate it from the surrounding areas it becomes less of a bioregional reinforcement, and more of an intentional creation of island geography; and the latter is known for reducing, not preserving, biodiversity. Indeed, bioinvasion may be seen in two contrasting lights with regard to the need for prevention. One the one hand, it is clear (economic activity as causation aside) it must be stopped, because it is a threat to biodiversity. Beyond the economic costs it can entail, the ultimate threat is to the local fauna and flora in the region affected.

On the other hand, the principle of non-intervention may apply, since purple loosestrife and pine beetles are living things, with an inherent right to life as well; they are an intrinsic part of the very biodiversity they are in effect damaging. Of course, this is the stuff of environmental ethics, not international politics, though there are some analogies of interest. Charges of speciesism (the view that some species have precedence over others due to an innate ordering of intrinsic value; see VanDeVeer, 1979) are inevitable here. And reasonable: surely we consider the sea lamprey less valuable than the sea otter, though we do not, generally, eat (catch, harvest) sea otters. Undoubtedly, 
parasites fail to appeal to our aesthetic values. True, some keystone species are with sound reason held above others in the field of conservation management, but they are viewed as the threatened, and not the threatening, players in the game. ${ }^{9}$ Mystic ecology, as Murray Bookchin suggests, conveniently ignores "the need to deal with pathogenic microbes, animal vectors of lethal diseases, earthquakes, and typhoons, to cite less aesthetically satisfying beings and phenomena than whales, grizzly bears, wolves, and mountains" (1994: 22). ${ }^{10}$ Our understanding of evolution is of primary importance here. We would be rather dishonest if we denied the fact that natural selection favors opportunistic invasive species, even if we are laden with guilt about our own role in getting them started. It would also be misleading if we assumed that ecological equilibrium existed prior to invasion; ecosystems are in a constant state of flux. Our will to power, in Nietszche's terms, is both evident and misapplied when we attempt to recreate an idyllic past that never truly existed (see Madore, 2006).

Meanwhile, each of the mainstream theories/approaches to IR will find some sort of fit, albeit an awkward one, with the concerns and threats to biosecurity posed by both real and imagined invasive alien species. The fact that such theorization emanates largely from the so-called "first world", source of the great human migrations and imperial impositions of the last 500 years, is more than ironic; voices from the periphery continue to be silenced by the waves of historical interpretation. Even the frontier mythology of American socio-economic development - the restless surge westward, complete with barbed-wire fences and sprawling manicured suburbs - should make the most ardent nationalist feel a common link with IAS. Of course, much IR theory is partially premised on the need for defense from various models of invasion, but IAS are not any easy fit with models of deterrence; liberal internationalists would prefer mutually beneficial institutions to provide intervention opportunities; critical theorists would reach deeper and ask for some form of restructuring of the global economy or enabling mental paradigm. We need to hear more from those most directly affected by major IAS events, so they can contribute to the conceptual discussion prompted by this issue-area. We need to infuse the question of justice into the debate, lest it be dominated entirely by those simply concerned with defeating the urge to conclude that IAS, and other transborder pollution issues, make the juxtaposition of land and territory ethically and intellectually absurd.

Commentators are often concerned that the language of invasive biology, with its references to natives, non-natives, aliens, and other classifications, can add weight to social theory that promotes xenophobia and racism (Subramaniam, 2001). This is certainly a worthy concern, though anthropological studies may indicate this is a subtler

\footnotetext{
${ }^{9}$ They are also, of course, culturally defined: see Cristancho and Vining, 2004.

${ }^{10}$ Bookchin is responding largely to the deep ecology of Arne Naess (see Seed, et. al., 1988). He goes on: "This selective view of 'Mother Nature's' biotic and physiographic inventory has raised some stormy problems for mystical ecology's message of universal salvation" (ibid). Some deep ecologists may view IAS as nature's way of clearing the ground for future explosions of biodiversity, though most, I suspect, would agree that IAS are one aspect of nature where lethal human intervention is probably necessary for the greater good.
} 
problem than a blanket condemnation of the cultural construction of alien species suggests (see Helmreich, 2005). IAS have been defined as such because they threaten some facet of human desirability, be it children's health, cherished species, or agricultural preferences. Science will reflect this normative context, regardless of any claims to universality that may be made, and cultural sensitivity will be as vital in the effort to curb truly harmful IAS as it is in any other policy realm. While it would be chimerical to expect to curb all IAS, or to return to some phantasmal natural state of permanent equilibrium, it would be equally foolhardy not to protect ourselves against them, or at least strive to limit their impact on our own survival. At the international level this necessitates multilateral policy co-ordination on a broad scale, often referred to as global governance. However, many of the challenges this poses can be found at the national, regional, and even municipal levels as well.

\section{IAS: Challenges to Global Governance}

In 1996, a Norway/United Nations conference on alien species assembled technical experts from some eighty states under the rubric of the Convention on Biological Diversity. They concluded that invasive alien species posed one of the greatest threats to global biodiversity; that most countries had "insufficient awareness, information or capacity" to deal with the problem, and that knowledge and possible solutions were not being shared effectively amongst affected states. ${ }^{11}$ Clearly, invasive species are an international problem - so much so that it was customary until recent decades to even define invasive species according to the criterion that they had effectively crossed borders. It is no surprise, then, that there have been notable multilateral efforts to publicize and deal with the issue in general, perhaps most famously with the SCOPE (Scientific Committee on Problems of the Environment), and the Ecology of Biological Invasions Programme, begun in the 1980s, and now referred to as the Global Invasive Species Programme, or GISP (see Ruiz and Carleton, eds., 2003, CBD, 2001 a and b). This represents an effort to catalogue and recommend remedial action for thousands of invasive species identified to date. Other organizations involved include the Food and Agriculture Organization (FAO), which hosts the Secretariat of the International Plant Protection Convention (1952); the aforementioned International Convention for the Management of Ballast Water and Sediments (2004), to be administered by the International Maritime Organisation (IMO); and the Convention on Biological Diversity. Other organizations involved include: UNEP, the International Council for the Exploration of the Sea (ICES), IUCN (World Conservation Union)'s Invasive Species Specialist Group. ${ }^{12}$ Of these, the latter may be the most influential, as it gathers 146 members of the unique epistemic community of IAS specialists from over 40

\footnotetext{
11 The meeting spawned the Global Invasive Species Programme, discussed immediately below.

12 This is but a partial list. Others include: the Convention on Migratory Species of Wild Animals, the Convention on International trade in Endangered Species of Wild Fauna and Flora, the Convention on Wetlands of International Importance (Ramsar), the Convention on the Conservation of European Wildlife and Natural Habitats, the International Plant Protection Convention, Codex Alimentarius, DIVERSITAS, the Office International des Epizooties, UNESCO, and the WHO. See CBD 2001:573.
} 
different states. They help compose the Global Invasive Species Database; one can also find the "100 Worst" list on the appropriate website. ${ }^{13}$ The most visible multilateral mechanism, however, and the one which is constantly called upon by CBD members to do something concrete about the problem, is the GISP. ${ }^{14}$

It seems we have no shortage of multilaterally-funded organizations studying and publicizing this problem. But it is not evident that they operate in such a manner as to influence behavior on the ground or waters of international trade routes. In fact the most important preventive measure remains border control, which is administered at the national (or state, provincial, etc.) level. Nonethless, it would be churlish to dismiss the potential of multilateral and transnational approaches to this problem; at the same time, a realistic assessment of the associated dilemmas raises several pertinent questions, each worthy of much further study than can be offered here. I will stress five main themes which, taken as a whole, reflect the difficulties faced by efforts to establish an effective global governance regime related to invasive alien species. This is hardly (unfortunately) an exhaustive list; but I believe it is an essential one. Given the severity of the challenges, not even someone highly paid to do so would with ease underestimate the challenge we face. The most obvious problem to political scientists is the appropriate division of authority and labor. We might begin any discussion of political responsibility with reference to the widely accepted norm that governments, both local and national, bear the primary moral responsibility for policy development and implementation. Again, this would only be acceptable to most environmental ethicists if a bioinvasion is, essentially, anthropomorphically induced, though this is a rather blurred line in an age of climate change (see below). The only way to deal with the issue on a completely unilateral level would entail almost total dissociation from the global trading system, not to mention an absurdly fund-draining border control mechanism. It need not flow from this premise that international organizations, or even more vaguely, the international community, have/has a similar obligation.

However, advocates of global governance, including the architects of grand designs of institutionalized environmental co-operation (such as Esty and Ivanova, 2002), tend see the solution to common action problems in a liberal light; the obligation of curtailing a transnational menace imperious to the coercive power of any one state is, self-evidently, the creation of mechanisms to ensure co-operation. But it is not easy to see what those mechanisms can be in the case of IAS. While there are thousands of cases where bilateral transborder invasives necessitate commensurate diplomatic activity at that level, such as the Devil's Lake controversy between North Dakota and Manitoba (the latter fears a major diversion project south of the border will flood Canadian rivers and lakes with IAS), globalization demands a multilateral response to most cases, such as the zebra mussel, which is based on transnational ballast water discharge. Small island

\footnotetext{
${ }^{13}$ http://www.issg.org/database/species/search.asp?st=100ss\&fr=1\&sts=; top-ten winners include the black wattle tree of Australia; the Giant African snail; the myna bird of India, the Asian tiger and common malarial mosquitoes, the yellow crazy ant, and the Asian longhorned beetle.

${ }^{14}$ For example, Decision V/8 (8), adopted at the CBD COP in Nairobi, 2000, calls on the GISP (along with Parties and other governments) to "give priority attention to geographically and evolutionarily isolated ecosystems, and to use the ecosystem approach and precautionary and biogeographical approaches, appropriate" (CBD, 2001:573).
} 
states, for example, have no neighboring states to fear, but are very concerned with alien contamination of their forests due to tourism, investment, and natural resource exploration, and many have embarked on extensive, and expensive, IAS eradication programmes (see especially Veitch and Clout, 2002). ${ }^{15}$

The "exchange of best practices" mechanism, which is designed to encourage information-sharing as well as trump the competition problem, can only go so far in a world of astoundingly unequal resources. Even quarantine measures for live animals, for example, are subject to wild discrepancies of implementation success rates in different states. The GISP can disseminate valuable information about what species can cause problems if permitted in sensitive regions, but there is no guarantee such warnings will be taken seriously. Further, it is vital that there is sufficient involvement of the various sectors involved, which is, quite simply, vast, ranging from fisheries, agriculture, aquaculture, forestry, horticulture, shipping, ground and air transportation, construction, landscaping, ornamental aquaculture, tourism ${ }^{16}$ and game-farming, and others.

Eradication measures offer another opportunity for both co-operative best practices sharing and for self-defeating ecosystem destruction (the infamous effort to rid Australia of invasive rabbits is a clear example).

It would seem that the international community faces a familiar dilemma with regard to the question of authority: there is no truly international "authority" in the sense of coercive abilities, and there is also a great deal of overlap between different groups, all with some stake or voice staked in the issue-area. States might well consider the benefits of investing heavily in one of them, such as the GISP, so that resources are not squandered on replicated work, and the public impact of GISP is as forceful as possible. But the task of intervening in the world economy with regulations designed to restrict the spread of IAS will remain largely in the hands of border control agents and national shipping regulators and agricultural policy and conservation policy enforcement officers, and they in turn will only be spurred to serious action by national governments. ${ }^{17}$ Hopefully, with efforts from the CBD and other extant agreements, we can move toward a Global Convention on IAS. But it would be premature to put our hope in this development, or in its proper implementation were it to come to light.

If such a Global Convention was constructed, it would need to address the question of state and individual responsibility; at present, we are nowhere close to solving this moral puzzle in universal fashion. It has certainly come to pass, through historical experiences such as the Trail Smelter Case, that there exists a general principle in

\footnotetext{
${ }^{15}$ Thus the Working programme for forest biological diversity under the CBD calls on states to promote "activities to minimize the impact of harmful alien species on forest biological diversity, particularly in small island developing states"; CBD 2001:484.

${ }^{16}$ Wildlife-oriented tourism is certainly a good thing for species conservation. However, we should be aware of the threats it poses as well. Beyond direct damage to habitat by coral-stomping snorkel gazers and safari-bound SUVs, such tourism increases the risk of pathogenic contamination from humans (and companion animals such as dogs or horses) to wild animals, and vice-versa, and the risk of introducing alien species into the area (and the risk of people taking them back to their own place of origin).

${ }^{17}$ Similarly, the ultimate implementation of CITES (the Convention on Trade in Endangered Species) is in the hands of border control agents; see Stoett, 2004, for discussion.
} 
international law that every state is obligated "not to allow its territory to be used in such a way as to damage the environment of other States or of areas beyond the limits of national jurisdiction"; further, according to what has become known as the Chernobyl principle, states are obligated to "notify other States of the possible risk that their environment may be damaged or affected by an accident that has occurred on its territory or in an area under its jurisdiction" (Cassese, 2001:381, 382). Further, and somewhat less clearly, Principle 15 of the Rio Declaration asserts that states should adopt the precautionary principle (which would preclude at least the deliberate introduction of IAS) and that the polluter should pay the costs of pollution "with due regard to the public interests and without distorting international trade and investment" (Principle 16).

Much of the liability issue is based on Article 14.1 (d) of the Convention on Biological Diversity, which stipulates that "each Contracting Party, as far as possible and as appropriate, shall ...In the case of imminent or grave danger or damage, originating under its jurisdiction or control, to biological diversity within the area under jurisdiction of other States or in areas beyond the limits of national jurisdiction, notify immediately the potentially affected States of such danger or damage, as well as initiate action to prevent or minimize such danger or damage." Article 14.2 stipulates that the Conference of the parties "shall examine, on the basis of studies to be carried out, the issue of liability and redress, including restoration and compensation, for damage to biological diversity, except where such liability is a purely internal matter."(CBD Secretariat, 2001: 148). We might note that this stipulation has been considered largely within the context of the framework of the Cartagena Protocol on Biosafety, and not related directly to invasive alien species.

At any rate, one should not exaggerate the significance of IAS under the CBD (nor, for that matter, should we exaggerate the impact of the CBD itself). In fact, beyond the extrapolated inference in Article 14 mentioned above, IAS emerge as noteworthy only in Article 8 (in-situ conservation)h, which demands contracting parties "prevent the introduction of, control or eradicate those alien species which threaten ecosystems, habitats, or species" (CBD Secretariat, 2001:105). The SBSTTA ${ }^{18}$ has considered questions related to IAS on numerous occasions, related principally to forest, marine and coastal, and inland water biodiversity, and has strongly urged the multilateral support of the GISP, particularly through the GEF. And several other COP decisions have referred to the customary legal principle that states avoid spreading risks in other states, either through intentional or unintentional transfer of IAS (even if it is harmless to the state of origin) or, even, the "intentional or unintentional introduction of an alien species into their own State if there is a risk of that species subsequently spreading (with or without a human vector) into another State and becoming invasive" (CBD 2001:576). But there is no mechanism to determine compensatory procedures or costs. The often diffuse nature of origin will hamper efforts in this direction; the lack of clear intentionality would curb legal efforts at prosecution.

\footnotetext{
${ }^{18}$ Subsidiary Body on Scientific, Technical and Technological Advice
} 
Further challenges involve the need for sustained public attention on the issue. Urban dwellers may have less first-hand experience of IAS than rural citizens. Rather, it will be those humans whose livelihoods are destroyed, and who often end up as internal displacees or economic migrants themselves, who will have the most at stake in the shortrun, and they typically have the least resounding political voices. Even in cases where the economic impact has been tremendous, and where there have been international implications, public knowledge has been notoriously impoverished. The many international organizations described above that work on this issue all have public knowledge dissemination on their agenda, and they will need continued assistance from affected communities, national governments, and academia alike to succeed. However, we can also look with some dismay at the Nile perch case, where exports of the carnivorous fish to Europe have in effect created an ecological and human disaster within the context of dependent development. In cases such as these, where local elites and even middle class employment has become based upon an industry derived from the commercial exploitation of IAS, we can expect little governmental effort to popularize the issue. Were zebra mussels delicious delicacies instead of simply navigational and commercial nuisances, we might hear even less about their highly problematic nature.

The involvement of science is central to the questions of public awareness as well as policy development. To some extent, conservation management is predicated upon the acceptance of what has been termed "paternalistic intervention" (Feinberg, 1986; VanDeVeer, 1986). For example, the selective culling of elephant populations might be justified because, as large land rovers capable of consuming vast quantities of food, rising elephant populations can threaten both wildlife conservation areas and much-needed agricultural land in sub-Saharan Africa. With most IAS, however, it is at best extremely difficult, and at worst counter-productive or ecocidal, to achieve this type of intervention here, unless we are able to pinpoint the target of eradication with unlikely precision. This implies an uncommonly heavy reliance on scientific investigation to assist in policy development. Yet if the need to integrate science with policy is obvious, caution is warranted, since those with specific interests will utilize science accordingly. Legitimate contestation is one thing; IAS are often fairly obvious, and injurious, so we might assume there will be little overt manipulation on such issues. But were this always the case, we would have less of a problem to deal with already. The fact is that science is based on the pursuit of predictive capacity, and it is notoriously difficult to predict the exact travel plans of IAS, as the discussion on climate change immediately below suggests. However, we can to some extent regulate trade according to scientific insight; for example, a new IMO-mediated ballast water agreement would seem vital based on the zebra mussel experience. The WTO and other bodies may be reluctant to accept this as an environmental imperative, but it certainly qualifies. At the same time, cultural sensitivity will need to be integrated with science-driven policy; none of the ethical dilemmas found in other areas of environmental politics will escape the IAS question.

All of these challenges meet yet another: the uncertainty provided by climate change. At the macro level, biodiversity is challenged by the centuries-long process of agricultural production, since it moves us toward homogenous ecosystems and is reliant on unnatural inputs, especially pesticides and oil byproducts, for increased yields. 
Reduced biodiversity increases vulnerability to IAS. Urbanization also presents a threat to biodiversity, since it drives demand for the extraction of natural resources.

Industrialization has introduced a wide array of carcinogens and other contaminants to the water supply, the food supply, and the air we breathe. We have in effect so altered the state of nature that changes at the microbial level may also be attributed to human activity. The extensive use of antibiotics, both by people and on farms, is an example. Excrement containing antibiotic residue gradually finds its way into the water systems, increasing the risk of water-borne infectious diseases. The dispersal of antibiotics could lead to the evolution of "superbugs", invasive species we, or the animals we raise in cramped conditions, would be unable to resist.

Globalization and global warming are increasing the likelihood of bioinvasions at both the microbial and species levels. As Andrew Price-Smith puts it, there is a "link between temperature increases and a shortened extrinsic incubation rate coupled with increased biting activity of many arthropod vectors... Since global environmental change is expected to generate significant long-term shifts in abiotic phenomena (temperature, humidity, water resources, etc.), we can reasonably expect attendant shifts in pathogenic virulence" (2002:168). There is evidence that warming trends will induce species migration northward, and this raises concerns about disease and threats to native species (see Hughes, 2000; McMichael and Bouma, 2001). However, such "unassisted migration" will prove difficult for rare species of plants and trees, and adaptation or extinction are as likely (see Iverson, et. al., 2004). Not so for insects: warming patterns have vastly extended the range of the mountain pine beetle, ravaging Yoho National Park in British Columbia and threatening forests in Washington; officials in Alberta are "setting fires and traps and felling thousands of trees in an attempt to keep the beetle at bay." 19 In the case of zebra mussels we might see northward migration as the appropriate reproduction temperatures are more common. Flooding could also expand zebra mussel territory even further. On the latter, it is believed that "...climate change will affect the incidence of episodic recruitment events of invasive species, by altering the frequency, intensity, and duration of flooding ... by allowing aggressive species to escape from local, constrained refugia" (Sutherst, 2000:224; Kolar and Lodge, 2000). It is especially difficult to predict the impact of climate change on northern areas, since the Arctic is such a vulnerable ecosystem. In general, we may be in for some nasty surprises, and the challenges this will pose to multilateral efforts at co-ordination will be commensurate. If globalization and global warming are increasing the likelihood of bioinvasions, then it is up to individuals, corporations, and governments to learn as much as possible about the process of identifying and reducing them before their spread becomes irreversible. As always, the need for scientific inquiry and education is as obvious as it is imperative. For its part, the scientific community must concern itself with "post-invasion biology"

\footnotetext{
${ }^{19}$ The pine beetle has swept across British Columbia, and scientists fear it will "cross the Rocky Mountains and sweep across the northern continent into areas where it used to be killed by severe cold ... U.S. Forest Service officials say they are watching warily as the outbreak has spread." The U.S. is less vulnerable because it "lacks the seamless forest of lodgepole pines that are a highway for the beetle in Canada." By the time we hear more about the beetle highway, it may be too late to recover. Quotes from Doug Struck, in an article written for the Washington Post and reprinted in The Montreal Gazette, "Our Forests Are a Feast", March 5, 2006, A10.
} 
(Carroll and Dingle, 1996) and restorative post-eradication policy as much as with preventive action.

This area of research is only beginning to materialize, though it will accelerate if climate change brings new and dangerous microbes to the industrialized states (of course, many would argue this is already occurring). There are many related issue-areas that are attracting both ethical and scientific enquiry. For example, the ethical issues presented by xenotransplantation (the transfer of tissue from one animal to another of a different species) have troubled scientists and ethicists alike since the immunologic basis of tissue rejection was discovered in the mid-1940s, eventually making transfers of organs possible by administering immunosuppressive drugs such as cycloporin that blocked the recipient's immune response to foreign proteins. As such scientific adventurism proceeds, the fear of xenozoonosis (an infectious agent introduced to humans by transplanted tissue) is a real one. This could be the ultimate example of an incidental IAS threatening human health. It is clear that we need international institutions, such as the WHO, to assume a leading voice on such issues, casting light on emerging practices; national governments need to at least permit the idea that public participation can take place with some strand of global equity in mind. However, it is just as clear that it will be corporate and national self-governance that matters more.

\section{Conclusion}

"We must make no mistake: we are seeing one of the great historical convulsions in the world's fauna and flora."

Charles Elton, 1958:31

This article has offered a preliminary exposition of some of the conceptual and governance challenges emerging from an increasingly prevalent shift in how we think of both the natural world on which we depend, and the impact of globalization on that world. While it is evident that we cannot stop IAS, multilateral efforts to curtail the harm they may cause are certainly warranted. While framing the debate in terms of territorial units may be limiting our understanding of the natural processes and social impact of invasive biology, states remain the central organized sources of policy implementation, and decision-makers will face the dilemmas described above.

Much of the imagery associated with invasion will find its way into the public discourse on IAS. The commensurate urge to defend precious land and water from the invader (in the case of locust invasions, the imagery is more akin to a massive air attack), persists. ${ }^{20}$ There will be endless debates over the appropriate international legal forum in which affected states can seek compensation for what they will characterize as negligence (or, worse, purposeful bioeconomic assault) on the part of exporting states. There is the need for multilateral policy co-ordination mechanisms, however weak and ineffectual

\footnotetext{
${ }^{20}$ Though not usually seen as IAS, migratory birds are already being discussed in this manner, since they bring the threat of avian flu with them.
} 
they may be in the immediate future, to develop robust capabilities, without infringing on sovereign jurisdictions. There are the inherent dilemmas found in any complex global systems level common action problem; and the corresponding need to educate the public about such complex issues. There is a social justice element, since invasive species tend to disproportionately impact the lives of farmers, fishers, and other largely working class people. Environmentalists will no doubt struggle with the normative implications of purposeful eradication campaigns; critical theorists will question the potential for authoritarian responses, and all the incidental benefits for oppressive states this can entail. ${ }^{21}$ Global governance experts will struggle with the twin demands of the protection of national sovereignty norms and the very real security problems presented by trade routes, border control, and human and animal migration.

None of this matters to invasive alien species, which can only proceed within their own teleology of expansion, engulfing local flora and fauna. Were they to have sufficient conscious awareness of all the problems they are causing, it is questionable whether they would find their own agency triumphant, or simply be thankful that human beings have such limited capacity for co-operation and foresight. It is high time for students of environmental and international politics to take them seriously, not only as threats to human security, but as partial reflections of the complex world we have created. Ultimately, counter-bioinvasion will require the re-examination of our collective and individual needs that green politics has always demanded.

\section{REFERENCES}

Aginam, O. (2005) Global Health Governance: International Law and Public Health in a Divided World. Toronto: University of Toronto Press.

Bookchin, M. (1994) "Will Ecology Become the 'Dismal Science'?” In Which Way for the Ecology Movement? Essays by Murray Bookchin. San Francisco: AK Press, 21-29.

Bright, C. (1999) "Invasive Species: Pathogens of Globalization." Foreign Policy, Fall:50-58.

Bright, C. (1998) Life Out of Bounds: Bioinvasion in a Borderless World. New York: Norton.

Carroll, S., and Dingle, H. (1996) "The Biology of Post-invasion Events." Biological Conservation (special issue: invasion biology), 207-214.

Cassese, A. (2001) International Law. Oxford: University of Oxford Press.

\footnotetext{
${ }^{21}$ See Peluso, 1993, for an earlier discussion of how conservation can facilitate authoritarian regimes.
} 
CBD (2001) (Convention on Biological Diversity Secretariat); Handbook of the Convention on Biological Diversity. London: Earthscan.

CEC (Commission on Environmental Co-operation, NAFTA). (2001). The North American Mosaic: A State of the Environment Report. Montreal.

Colautti, R., and H. MacIsaac. (2004) "A Neutral Terminology to Define 'Invasive' Species." Diversity and Distributions 10:135-141.

Courtenay, W., and P. Moyle. (1992) "Crimes Against Biodiversity: The Lasting Legacy of Fish Introductions." Transactions of the North American Wildlife and Natural Resources Conference, 56: 365-372.

Cox, G. (1999) Alien Species in North America and Hawaii: Impacts on National Ecosystems. Washington: Island.

Crivelli, A.J. (1995). "Are Fish Introductions a Threat to Endemic Freshwater Fishes in the Northern Mediterranean Region?” Biological Conservation, 72:2, 311-320.

Cristancho, S., and J. Vining. (2004) "Culturally Defined Keystone Species.” Human Ecology Review 11:2, 153-164.

Crosby, A. (1986) Ecological Imperialism: The Biological Expansion of Europe. Cambridge: Cambridge University Press.

De Lafontaine, Y., et. al. (2002) "Testing a new anti-Zebra mussel coating with a multiplate sampler." Biofouling 18:1, 1-12.

Dempsey, D. 2005. On the Brink: The Great Lakes of the $21^{\text {st }}$ Century. Michigan State University Press.

Di Castri, F. (1989) "History of Biological Invasions with Special Emphasis on the Old World." In J. Drake, et. al., Biological Invasions: A Global Perspective (Essex: SCOPE), $1-30$.

Edwards, K. (1998) “A Critique of the General Approach to Invasive Plant Species." In U. Starfinger, et. al., eds., Plant Invasions: Ecological Mechanisms and Human Responses (Leiden: Backhuys), 85-94.

Elton, C. (1958) The Ecology of Invasions by Animals and Plants. London: Methuen.

Esty, D., and M. Ivanova, eds. (2002) Global Environmental Governance: Options and Opportunities. New Haven: Yale School of Forestry and Environmental Studies.

Feinberg, J. (1986) Harm to Self. NY: Oxford University Press. 
Goodsell, J., and L. Kats. (1999) "Effect of introduced mosquitofish on Pacific Treefrogs and the role of alternative prey." Conservation Biology 13:921-924.

Greenough, P., and A. Lowenhaupt, eds. (2004) Nature in the Global South:

Environmental Projects in South and Southeast Asia. New Delhi: Orient Longman.

Hardin, G. (1968) “The Tragedy of the Commons.” Science, 162: 1243-1248.

Helmreich, S. (2005) "How Scientists Think; About 'Natives', for Example. A Problem of Taxonomy Among Biologists of Alien Species in Hawaii." Journal of the Royal Anthropological Institute. 11:107-128.

Hughes, L. (2000) "Biological Consequences of Global Warming: Is the Signal Apparent Already?" Trends in Ecology and Evolution 15:56-61.

ISSG/IUCN (Invasive Species Specialist Group/International Union for the Conservation of Nature). (2001) "100 of the World's Worst Invasive Species: a Selection from the Global Invasive Species Database", available at: http://www.iucn.org/biodiversityday/100booklet.pdf

Iverson, L., et. al. (2004) "How Fast and Far Might Tree Species Migrate in the Eastern U.S. Due to Climate Change?" Global Ecology and Biogeography 13:209-219.

Kaufman, L. (1996) "Why the Ark is Sinking." In same and K. Mallory, eds., The Last Extinction (Second edition) (Cambridge, Mass.: MIT Press), 1-46.

Kovel, J. (2002) The Enemy of Nature: The End of Capitalism or the End of the World? London: Zed.

Kolar, C., and D. Lodge. (2000) "Freshwater Nonindigenous Species: Interactions with Other Global Changes." In H. Mooney and R. Hobbs, Invasive Species in a Changing World (Washington: Island), 3-30.

Leland, J. (2005) Aliens in the Backyard: Plant and Animal Imports Into America. University of South Carolina Press.

Lizarralde, M. (1993) "Current Status of the Introduced Beaver Population in Tierra del Fuego, Argentina." AMBIO 22(6): 351-358.

Lounibos, L. (2002) "Invasions by Insect Vectors of Human Disease." Annual Review of Entomology 47:233-266.

Mador, D. (2006) "Nietzsche's Conception of Life as Overcoming: Implications for Managing Ecosystems." In E. Laferrière and P.Stoett, eds., International Ecopolitical Theory: Critical Approaches (Vancouver: UBC Press), 70-85. 
McMichael, A., and M. Bouma. (2000) "Global Changes, Invasive Species, and Human Health.” In H. Mooney and R. Hobbs, Invasive Species in a Changing World (Washington: Island), 191-210.

McNeely, J., et. al., eds. (2001) Global Strategy on Invasive Species. Gland: IUCN.

Miller, J., S. Engelberg, S., W. Broad. (2001) Germs: Biological Weapons and America's Secret War. New York: Simon and Schuster.

Mitchell, R. (1994) Intentional Oil Pollution at Sea: Environmental Policies and Treaty Compliance. Cambridge, MA: MIT Press.

Peluso, N.L. (1993) “Coercing Conservation: The Politics of State Resource Control.” In R. Lip schutz and K. Conca, eds., The State and Social power in Global Environmental Politics (New York: Columbia University Press).

Price-Smith, A. (2002) The Health of Nations: Infectious Disease, Environmental Change, and Their Effects on National Security and Development. Cambridge: MIT Press.

Reiter, P., and D. Sprenger. (1987) "The used tire trade: a mechanism for the worldwide dispersal of container breeding mosquitoes." Journal of the American Mosquito Control Association, 33:494-501.

Ruiz, G., and J. Carleton, eds. (2003) Invasive Species and Management Strategies. Washington: Island Press.

Sanders, J. and P. Stoett. (2006) "Extinction and Invasion: Transborder Conservation Efforts." In P. Le Prestre and P. Stoett, eds., Bilateral Ecopolitics: Continuity and Change in Canadian-American Environmental Relations (London: Ashgate), 157-178.

Schwartz, M.S. (1997) “Defining Indigenous Species: An Introduction.” In J. Luken and J. Thierst, eds., Assessment and Management of Plant Invasions (New York: SpringerVerley), 7-17.

Seed, J., J. Macy, P. Fleming, and A. Naess. 1988. Thinking Like a Mountain: Towards a Council of All Beings. Philadelphia: New Society Publishers.

Simberloff, D., and P. Stilting. (1996) "Risks of Species Introduced for Biological Control.” Biological Conservation (special issue: invasion biology): 185-192.

Smith, S. (2001) "Kelp Rafts in the Southern Ocean." Global Ecology and Biogeography 11:67-69. 
Stoett, P. (2004) "Wildlife Conservation: Institutional and Normative Considerations." In N. Schrijver and F. Weiss, eds., International Law and Sustainable Development:

Principles and Practice (Leiden, Netherlands: Martinus Nijhoff), 501-518.

Subramaniam, B. (2001) "The Aliens Have Landed! Reflections on the Rhetoric of Biological Invasions.” Meridians: Feminism, Race, Transnationalism 2:1, 26-40.

Sutherst, R. (2000) "Climate Change and Invasive Species: A Conceptual Framework." In A. Mooney and R. Hobbs, eds., Invasive Species in a Changing World (Washington: Island), 211-240.

Theodoropoulas, D. (2003) Invasion Biology: Critique of a Pseudoscience. Blythe, California: Avvar Books.

VanDeVeer, D. (1986) Paternalistic Intervention. Princeton: Princeton University Press.

Van Driesche, J., and R. van Driesche. (2000) Nature Out of Place: Biological Invasions in the Global Age. Washington: Island.

Veitch, C., and M. Clout. (2002) Turning the Tide: The Eradication of Invasive Species. Proceedings of the International Conference on Eradication of Island Invasives. Gland: Occasional Paper of the IUCN Species Survival Commission No. 27.

Vermeij, G. (1996) “An Agenda for Invasion Biology.” Biological Conservation 78:3-9. 